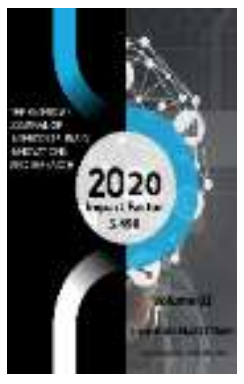

Journal Website: http://usajournalshub.c om/index,php/tajiir

Copyright: Original content from this work may be used under the terms of the creative commons attributes 4.0 licence.

\section{Ethnoculture Of The Baltic Nation In Turkestan (1867-1917yy.)}

Daiga Straupeniece

Researcher Lepaja University, Latvia. Lepaja, Litvia

Sherzodjon Choriev

Phd National University Of Uzbekistan, Tashkent, Uzbekistan

\title{
ABSTRACT
}

This article is devoted to the history of ethnocultural problems of the Baltic peoples who lived in the Turkestan general-governorship. The study also analyzed data on the lifestyle, regional distribution, religious issues, professions and economic life of the Baltic peoples. In addition, the article contains information from secret archival documents about Estonian Karl and a girl from Latvia Lota.

\section{KEYWORDS}

Ethnoculture, Baltic Nation, Turkestan general-governorship, Religion, Marital status, Regional distribution, The National Archive of Uzbekistan, Census of the Russian Empire, Latvian, Lithuanian, Estonian.

\section{INTRODUCTION}

The Turkestan region has long been known as Turan, Transoksaniya, Movaraunnahr, and in 1924, as a result of the policy of national territorial delimitation pursued by the Soviet government in the Turkestan ASSR, the republics of Uzbekistan, Kazakhstan, Kyrgyzstan, Turkmenistan and Tajikistan were formed. After these political processes, the region began to be called Central Asia among world political scientists. Not only Turks, but 
also many other tribes have lived in Turkestan since ancient times, sometimes as nomads and settlers. Also, during the reign of A.Temur, during the Central Asian khanates, many other nationalities lived in these areas as tourists, traders and other professionals.

After the occupation of the Russian Empire, the Turkestan region was formed in 1865 and in 1867 became as a Turkestan generalgovernorship. Initially, during these occupations, representatives of European peoples massively came to Turkestan as the military of the Russian Empire. From this period, the mass migration of the Baltic peoples to Central Asia began.

At the same time, in Turkestan, there were more than 20 ethnic groups [1Saipova K. D. 2016], but today in Uzbekistan, there are more than 140 ethnic groups and the Baltic peoples are a minority.

There are serious reasons for Uzbekistan to pay attention to this issue. Firstly, the policy of tolerance of the Republic of Uzbekistan, and secondly, economic, cultural and diplomatic development between the Republic of Uzbekistan and the Baltic countries is entering new stages.

The people of the Baltic have their own ancient ethnocultural history and play a significant role in the socio-political life of

Turkestan. In the Turkestan GovernorGeneralship, Turkestan ASSR and in Uzbekistan, many representatives of this nation have worked in the fields of art, science, education, technology and contributed to the development of the republic.

\section{RESEARCH METHOLOGY}

Nowadays, a lot of research work has been done on this topic. From history, it is known that in historical studies of the Soviet period special attention was paid to the history of the formation of Soviet power on the basis of primary archival materials. In particular, A.I. Matveev, G.Sh. Inoyatov, F.Kh.Narkhodzhaev in their studies on the history of the formation of Soviet power partially affected the political significance of the Baltic peoples in these political processes. Books on the history of Uzbekistan created in the Soviet era focus on information on their political activities. In his studies, L.I. Zhukova paid special attention to the religious problems of the Baltic peoples in Turkestan [1].

After the independence of the Republic of Uzbekistan, as a result of the government's policy of tolerance in the multinational republic, a lot of research has been conducted on this topic in the field of history. The collection "Ethnic Atlas of Uzbekistan" [2], published in 2002 under the leadership of A. Ilkhomov, provides information on the history of migration of Latvians, Lithuanians and Estonians to Uzbekistan and the history of their diaspora. In 2004, O.V. Lisitskaya focused on the religious issues of the Baltic nation, as well as professor R. Murtazaeva and K.Saipova focused on statistics on the diaspora and their social role in Uzbekistan [4]. In his monograph, R. Khomitov [5] tried to take a comprehensive approach to the history of cooperation between Uzbekistan and the Baltic States, while Sh. Choriev [6] on his article detailed the history of the Baltic diaspora in Uzbekistan.

It should be noted that, A. Nazarov [7], Z.B. Rakhmonkulova [8], Sh.Choriev [9] in their studies are devoted to the source study role and problems of creating a digital heritage of 
archival documents of the general - governor of Turkestan.

Many foreign studies have been conducted on the subject, including A.V. Gornukhova, N.A. Polovnikova, S.I. Brook, V.M. Kabuzan, T. Ivanova, V.A. Iontsev, N.M. Lebedeva, M.V.Nazarov, A.V.Okorokov, A.G. Ratin, T.Raun L.Sakkeus J.Vernant's articles and monographs deserve special mention [10].

There are also primary sources on this subject, such as archival materials, periodicals, and general census materials (1897).

Nowadays, more than 1.8 million historical documents are stored in the National Archives of Uzbekistan, for example, in the funds of the Turkestan general-governorship I-1, I-461, I-17, I$450,336,1-19,1-17$ it can be found a lot of historical information on this issue.

Turkestanskie Vedomosti and other periodicals, as well as census documents contain statistical data on the life of the Baltic peoples. The research methodology plays an important role in a scientific paper. The method of statistical analysis was effectively used analyzing the above mentioned sources. The method of comparative analysis was widely used for analyzing secondary sources.

A general statistical analysis of the population is important when conducting studies on the history of ethno culture, and for this, data on the total number of Baltic peoples were clarified. At the next stage, data on their religious relations and literacy were analyzed, and information on family relationships was studied. However, the study mainly used archival materials stored in the National Archives of Uzbekistan and scientific work carried out in Uzbekistan. Archival materials on the subject can also be found in the archives of Uzbekistan and other Central Asian countries,
Russia and the Baltic States. However, detailed identification and scientific circulation of these archival materials requires special experts and scientific research.

\section{A Brief History Of The Migration Of The Baltic Peoples To Turkestan Governor- Generalship}

A lot of research has been done on the history of migration of the Baltic peoples. In the study, the migration processes of the Baltic nations throughout Russia are studied in four stages: The first stage: from 1860 to the Crimean and Samara regions, partially to the Central Asian region. The second stage: Beginning in 1870, the governments of the Caucasus, Stavropol, Kuban, the central regions of Russia, Siberia and Central Asia. The third stage includes the territories of the Caucasus, the Black Sea region, the territories of Siberia, Tver and Central Asia from 1884 to 1886 . The fourth stage was moved from 1900 to 1917 to Siberia, Tomsk, Tobolsk and Turkestan [12]. As mentioned above representatives of the Baltic people first appeared in Central Asia as part of the Russian troops in the mid-6os of the XIX century. Most of the migrant population lived in Turkestan, partly in the Russian settlements of Bukhara and Khorezm, in the territories surrounding the Russian Empire. The main goal of the Russian settlements in these areas was to support the Russian military in the struggle against the local population with armed conflicts, only in 1903-1913, 116 Russian settlements were created in Turkestan [13]. In Russian settlements not only of Russian origin, but also of other European ethnic groups, including Latvian, Lithuanian and Estonian. According to the census of 1897, the Baltic peoples of the country were the lowest in the Turkestan population (Turkestan, Bukhara, 
Khorezm) and consisted of 287 (168 men, 119 women) [14].

Representatives of the Latvian nationality for the first time appeared in Central Asia as a part of the Russian troops in the mid-6os of the XIX century. Later, a small number of Latvians skilled workers, officials, teachers, doctors, and servants - settled in Turkestan. Most of them were engaged in craft, trade, and belonged to the petty-bourgeois stratum. In 1905, the church Evangelical Lutheran parish as a whole 150 Latvians visited the city of Turkestan. Central Asia has become a haven for of many Latvian revolutionaries who went underground. WW I marked a new stage in the resettlement of Latvians in the region. By the end of 1915, no less than 1,5 thousand refugees from all historical and cultural regions of Latvia (that time governorates of Courland, Livland and cultural region of Latgale that belongs to the Vitebsk governorate of Russian Empire), later about 600 people re-evacuated from them. The Latvian Society was created on this basis. Already later, in the 20s, the PolishLatvian National Bureau under the Council of National Minorities was established to regulate the lives of the multi-ethnic population of Turkestan.

In the late 60s. XIX century. in the Russian army in Turkestan were and Lithuanians. A little later, Lithuanian-born civilians with Russian citizenship began to arrive here. At the beginning of the last century, the Lithuanians made up a significant share in the pettybourgeois stratum of Tashkent, Samarkand and the cities of the Fergana Valley. Among those who came from the western national regions of the Russian Empire in Turkestan, there were about 1,000-1,200 Lithuanians. Since 1902, the main curator of Catholics of the Central Asian region Lithuanian priest Justin Pranaitis is appointed (1861-1917). Thanks to his energy and talent leader in the capital of the Turkestan Governor-General of the capital - a priest's house is being built in Tashkent, temporarily replacing prayer house, and a beautiful Roman Catholic church, as well temples in Samarkand and Skobelev From the moment of the arrival of the father of Pranaitis, the mass in the Tashkent Catholic Church and other Lithuanian concentration centers during his official business trips were conducted, in addition to Russian, Polish, and in Lithuanian. Some Lithuanians were Lutherans and attended evangelical Lutheran churches. In 1905, there were 10 Lithuanians in the Tashkent parish Lutheran. Their number significantly increased during the First World War at the expense of prisoners of war and refugees. Most Lithuanians headed to Tashkent, the Syrdarya and Samarkand regions. In December 1915, the priest Justin Pranaitis prepared a shelter for refugees from Lithuania. In the dormitory at the "Polish Church" more than 60 people were employed and provided with work. Many of them were able to return home in the spring of 1916. In February 1917, Justin Pranaitis died. The next curator was father Bronislav Ruthenis from Lithuania. In the province Father Rutenis was engaged in religious activities for over twenty years.

At the turn of the XIX $-X X$ centuries on the lands of present-day Uzbekistan settled and Estonian peasants, but in small quantities. Near Tashkent, in the lower part of the Kugart valley, there were several Estonian families. The list of persons of the Lutheran religion (1886), who lived in the Russian part of Tashkent, included the tradesman of the Estland gubernia Otto Redlin as well as in the Andijan district of Fergana region, three farms, about 30 inhabitants of whom were engaged in farming and animal breeding, and quite successfully. Estonian peasants, in comparison with the situation of peasant migrants of Slavic 
nationalities, lived many times more prosperously, using the cheap labor of both the indigenous and Russian population. Estonians took an active part in the activities of the community of Baltic immigrants, zealously observed all religious rituals and traditions of his people. In 1905, the Evangelical parish as a whole was registered 100 Estonians. Some Estonians professed Orthodoxy. After reevacuation of World War, I refugees in Central Asia there are about 200 Estonians left. According to data sheets of evangelical Lutheran societies, in the 20s. XX century. Estonians lived in Tashkent, Samarkand, Fergana and Kokand. In the late 30s. a small number arrived again in Central Asia Estonians evicted from the border regions of the USSR and Finland [15].

III. Materials Of The General Census In 1897 As A Source On The History Of The Ethnocultural Life Of The Baltic Nation In The Turkestan Governor-Generalship

The Baltic people first appeared in Central Asia as part of the Russian troops in the mid-6os of the XIX century. Most of the migrant population lived in Turkestan, partly in the
Russian settlements of Bukhara and Khorezm, in the territories surrounding the Russian Empire. The main goal of the Russian settlements in these areas was to support the Russian military in the struggle against the local population with armed conflicts, only in 19031913, 116 Russian settlements were created in Turkestan. In Russian settlements not only of Russian origin, but also of other European ethnic groups, including Latvian, Lithuanian and Estonian [16].

\section{REGIONAL DISTRIBUTION}

The National Archives of Uzbekistan keeps records of the 1897 census of the Russian Empire, which it can be clarify the ethncultural history of the Baltic peoples of Turkestan. According to the census of 1897, the Baltic peoples recorded as Kurland's, Liflands and Estlands.

The following table shows the statistical data analyzed by sex of the population of the Kurland, Lifland and Estland provinces living in Turkestan (1-table):

\section{1-table}

\section{Regional distribution of Baltic nation in Turkesstan}

(NAUz, The first general census of the population of the Russian Empire, 1897., 1904.)

\begin{tabular}{|c|c|c|c|c|c|c|c|c|c|c|c|}
\hline \multirow{2}{*}{$\begin{array}{c}\text { Name } \\
\text { of } \\
\text { Natio } \\
\text { ns }\end{array}$} & \multicolumn{2}{|c|}{$\begin{array}{c}\text { Syrdarya } \\
\text { oblast }\end{array}$} & \multicolumn{2}{|c|}{$\begin{array}{c}\text { Samarkand } \\
\text { oblast }\end{array}$} & \multicolumn{2}{|c|}{$\begin{array}{c}\text { Fergana } \\
\text { oblast }\end{array}$} & \multicolumn{2}{|c|}{$\begin{array}{c}\text { Semirechins } \\
\text { kiy oblast }\end{array}$} & \multicolumn{2}{|c|}{$\begin{array}{c}\text { Transcaspian } \\
\text { oblast }\end{array}$} & \multirow[t]{2}{*}{$\begin{array}{l}\text { Ove } \\
\text { ral }\end{array}$} \\
\hline & $\begin{array}{c}\text { Ma } \\
\text { le }\end{array}$ & $\begin{array}{c}\text { Femal } \\
\text { e }\end{array}$ & $\begin{array}{c}\text { Mal } \\
\text { e }\end{array}$ & $\begin{array}{c}\text { Femal } \\
\text { e }\end{array}$ & $\begin{array}{c}\text { Mal } \\
\text { e }\end{array}$ & $\begin{array}{c}\text { Femal } \\
\text { e }\end{array}$ & $\begin{array}{c}\text { Mal } \\
\text { e }\end{array}$ & $\begin{array}{c}\text { Femal } \\
\text { e }\end{array}$ & $\begin{array}{c}\text { Mal } \\
\text { e }\end{array}$ & $\begin{array}{c}\text { Femal } \\
\text { e }\end{array}$ & \\
\hline $\begin{array}{c}\text { Kurla } \\
\text { nd }\end{array}$ & 30 & 17 & 16 & 7 & 12 & 12 & 11 & 5 & - & - & 110 \\
\hline
\end{tabular}


The American Journal of Interdisciplinary Innovations and Research (ISSN-2642-7478)

Published: October 21, 2020 | Pages: 40-52

Doi: https://doi.org/10.37547/tajiir/Volumeo2Issue10-08

\begin{tabular}{|c|c|c|c|c|c|c|c|c|c|c|c|}
\hline $\begin{array}{c}\text { Liflan } \\
\text { d }\end{array}$ & 25 & 30 & 24 & 18 & 9 & 9 & 20 & 12 & - & - & 147 \\
\hline $\begin{array}{c}\text { Estlan } \\
\text { ds }\end{array}$ & 12 & 13 & 7 & 3 & 2 & 1 & & 2 & - & - & 43 \\
\hline $\begin{array}{c}\text { Overa } \\
\text { II }\end{array}$ & 67 & 60 & 47 & 28 & 23 & 22 & 34 & 19 & - & - & 300 \\
\hline
\end{tabular}

According to the census, 44 Baltic citizens were registered in the Syrdarya region, including 11 of them was recorded in the city of Tashkent and 3 of them was recorded in the Avliyatauezd. Also, the Baltic nations were registered in the Kazalinsk, Perovsky and Shymkent uezds of the Syrdarya oblast [17]. In the Fergana region they mainly lived in the uezds of Margilan, Andijan, Kokand and also in New Margilan were registered 7 Latvians [18]. The majority of the Baltic nationalities living in Samarkand province lived in Samarkand city and the rest of them were registered in Kattakurgan uezd.

\section{RELIGION}

The census also provides important information on the religious beliefs of the Baltic peoples living in Turkestan. The Baltic nations believed in Christian Orthodox, Roman Catholic and Lutheran faiths. However, according to the census, one can see reformists who adhered to ancient Christian traditions, and even those who converted to Islam among the Baltic people (2, 3 table).

\section{2-table}

Religious attitudes of Baltic nation in Turkestan

(NAUz.The first general census of the population of the Russian Empire, 1897.1905 y.)

\begin{tabular}{|c|c|c|c|c|c|c|c|c|}
\hline & \multicolumn{2}{|c|}{ Orthodoxy } & \multicolumn{2}{|c|}{$\begin{array}{l}\text { Religious } \\
\text { literacy }\end{array}$} & \multicolumn{2}{|c|}{$\begin{array}{l}\text { Roman } \\
\text { Catholic }\end{array}$} & \multicolumn{2}{|c|}{$\begin{array}{l}\text { Religious } \\
\text { literacy }\end{array}$} \\
\hline & Male & $\begin{array}{c}\text { Femal } \\
\text { e }\end{array}$ & Male & $\begin{array}{c}\text { Femal } \\
\text { e }\end{array}$ & Male & $\begin{array}{c}\text { Femal } \\
\text { e }\end{array}$ & Male & $\begin{array}{c}\text { Femal } \\
\text { e }\end{array}$ \\
\hline Syrdarya oblast & 1 & - & 1 & - & 16 & 3 & 15 & 2 \\
\hline Samarkand oblast & 2 & 3 & 1 & 2 & 8 & 3 & 6 & 3 \\
\hline Fergana oblast & 1 & 1 & 1 & 1 & 3 & 2 & 2 & 2 \\
\hline Semirechya oblast & 2 & - & 1 & - & 2 & - & 2 & - \\
\hline Transcaspian oblast & - & - & - & - & - & - & - & - \\
\hline
\end{tabular}


3-table

(NAUz.The first general census of the population of the Russian Empire, 1897.1905 y.)

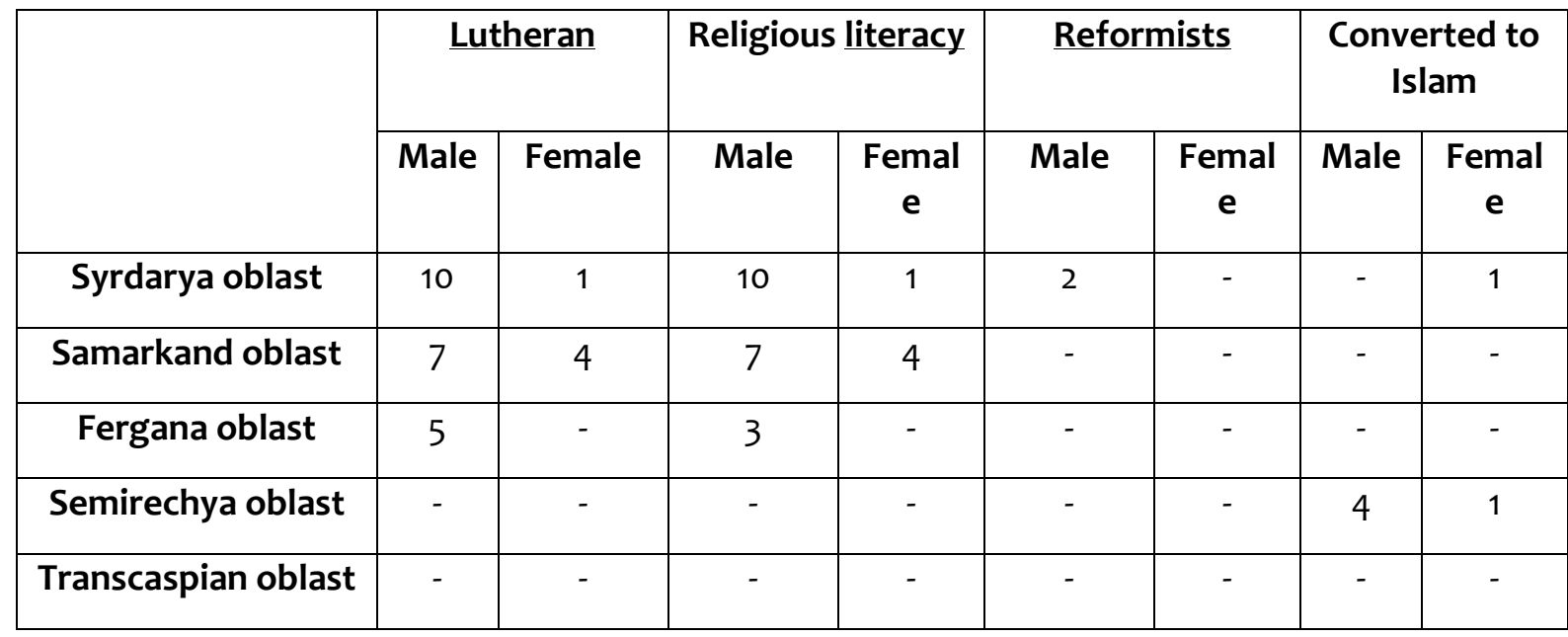

On Census the Baltic peoples was records as a Lithuanian-Latvians. Among the LithuanianLatvian nationalities in Turkestan, one man in Tashkent and 3 men and one woman in the Prezhevalsk uezd of Semirechye were captured as a Muslims.

The documents also contain information on the religious literacy of each person, which shows that the Baltic peoples of the Orthodox,
Roman Catholic and Lutheran faiths have high religious literacy.

\section{MARITAL STATUS}

The census statistics also provide important information about the marital status of the Baltic peoples living in Turkestan (4-table).

\section{4-table}

\section{Marital status Baltic nation in Turkestan}

(NAUz, The first general census of the population of the Russian Empire, 1897., 1905 )

\begin{tabular}{|c|c|c|c|c|c|c|}
\hline \multirow{2}{*}{ Name of the province } & \multicolumn{3}{|c|}{ Single } & \multicolumn{2}{c|}{ Married } & \multicolumn{2}{c|}{ Divorced } \\
\cline { 2 - 7 } & Male & Female & Male & Female & Male & Female \\
\hline Syrdarya oblast & 17 & 2 & 11 & 2 & - & - \\
\hline Samarkand oblast & 17 & 7 & 4 & 2 & - & - \\
\hline Fergana oblast & 7 & 3 & 2 & - & - & - \\
\hline Semirechya oblast & 6 & 1 & 3 & 1 & - & - \\
\hline Transcaspian oblast & - & - & - & - & - & - \\
\hline
\end{tabular}


The table shows that, among the Baltic people was more single and married men, however it can be seen that number of a single females were higher. Based on this table, it can be seen that there are no divorces among the families of the Baltic peoples, this will lead to the conclusion that they strictly followed their family traditions [19].
Professional and economic life. The Documents also contain important information on occupations and economic activities of the Baltic peoples in Turkestan (5-table).

\section{5-table}

Professional and economic life of Baltic nation in Turkestan (NAUz, The first general census of the population of the Russian Empire, 1897. 1905. )

\begin{tabular}{|c|c|c|c|c|c|c|c|c|c|c|}
\hline \multirow[t]{2}{*}{ Profession } & \multicolumn{2}{|c|}{$\begin{array}{c}\text { Syrdarya } \\
\text { oblast }\end{array}$} & \multicolumn{2}{|c|}{$\begin{array}{c}\text { Samarkan } \\
\text { d oblast }\end{array}$} & \multicolumn{2}{|c|}{$\begin{array}{c}\text { Fergana } \\
\text { oblast }\end{array}$} & \multicolumn{2}{|c|}{$\begin{array}{l}\text { Semirech } \\
\text { ya oblast }\end{array}$} & \multicolumn{2}{|c|}{$\begin{array}{l}\text { Transcasp } \\
\text { ian oblast }\end{array}$} \\
\hline & $\begin{array}{c}\text { Ma } \\
\text { le }\end{array}$ & $\begin{array}{l}\text { Fem } \\
\text { ale }\end{array}$ & $\begin{array}{c}\text { Ma } \\
\text { le }\end{array}$ & $\begin{array}{l}\text { Fem } \\
\text { ale }\end{array}$ & $\begin{array}{c}\text { Ma } \\
\text { le }\end{array}$ & $\begin{array}{l}\text { Fem } \\
\text { ale }\end{array}$ & $\begin{array}{c}\text { Ma } \\
\text { le }\end{array}$ & $\begin{array}{l}\text { Fem } \\
\text { ale }\end{array}$ & $\begin{array}{c}\text { Ma } \\
\text { le }\end{array}$ & $\begin{array}{l}\text { Fem } \\
\text { ale }\end{array}$ \\
\hline Administration and court & & & 7 & 1 & & & & & - & - \\
\hline Public and estate service & 3 & & & & & & & & - & - \\
\hline Military establishment & 8 & & & & 3 & 2 & & & - & - \\
\hline $\begin{array}{c}\text { Medical and sanitary } \\
\text { actions }\end{array}$ & 10 & 3 & 3 & & & & & & - & - \\
\hline Mine & 2 & & & & & & 1 & 1 & - & - \\
\hline $\begin{array}{l}\text { Means of treasury and } \\
\text { public institutions of } \\
\text { private individuals }\end{array}$ & & & & & & & & & - & - \\
\hline Agriculture & 2 & 3 & & & & & & & - & - \\
\hline Making clothes & 1 & 1 & & & & & 4 & & - & - \\
\hline Railways & 1 & & & & & & & & - & \\
\hline Trade intermediation & 1 & & & & & & & & - & - \\
\hline Private servants & & & & & & & & & - & - \\
\hline livestock & & & & & & & 1 & & - & - \\
\hline woodprocessing & & & & & & & 1 & & - & - \\
\hline
\end{tabular}


The American Journal of Interdisciplinary Innovations and Research (ISSN-2642-7478)

Published: October 21, 2020 | Pages: 40-52

Doi: https://doi.org/10.37547/tajiir/Volume02Issue10-08

\begin{tabular}{|c|l|l|l|l|l|l|l|l|c|c|}
\hline $\begin{array}{c}\text { Trade without any } \\
\text { precise definition }\end{array}$ & & & & & & & 1 & & - & - \\
\hline $\begin{array}{c}\text { Science, Literature and } \\
\text { Arts }\end{array}$ & & & & 2 & & & & - & - \\
\hline $\begin{array}{c}\text { Activities andprivateprovi } \\
\text { ders }\end{array}$ & & 1 & 7 & & & & & - & - \\
\hline $\begin{array}{c}\text { Capital and real estate } \\
\text { income of parents and } \\
\text { relatives }\end{array}$ & & & 1 & & & & & & - & - \\
\hline $\begin{array}{c}\text { Housing construction } \\
\text { Post and Telegraph }\end{array}$ & & & 2 & & & & & & - & - \\
\hline $\begin{array}{c}\text { Loan and weighted } \\
\text { commercial } \\
\text { establishment }\end{array}$ & & & 1 & & & & & & - & - \\
\hline \begin{tabular}{c} 
Fishing and hunting \\
\hline
\end{tabular} & & & & & & & 1 & & - & - \\
\hline
\end{tabular}

According to a table analysis of census materials, the Baltic peoples in Tashkent worked in the military, medical, sanitary, and public sectors, and in the Samarkand region the regional and judicial administrations, private entrepreneurship, post, telegraph and construction.

In Ferghana region, they mainly worked in the military, scientific, literary and art sciences, as well as in the area of Semirechye, they worked in tailors, forestry, livestock, mining and trade [20].

The National Archives of Uzbekistan does not keep records of the census of the Caspian region, but there is a report collection entitled "Commentary on the Caspian Region" which belong to in 1899. According to the collection, in the region in 1899 there were statistics of Russian, German, French, Polish, Greek nationalities living in Mangyshlak,
Krasnavodsk, Ashgabat, Tajan, Merv(they were uezds of the Trans-Caspian oblast). The Latvian-Lithuanian is not specifically recorded, however, there were registered 22 other nationalities.

In general, in the general census documents show that in 1897 in Turkestan, there were 300 Kurlands, Liflanders and Estonians.

They lived mainly in Tashkent, Kazalinsk, Perovsk, Shymkent districts of Syrdarya region, and in Margilan, Andijan, Kokand, New Margilan cities of Fergana region, as well as in Samarkand and Kattakurgan regions.

The Baltic peoples of the country practiced Orthodox, Roman Catholic, and Lutheran religions, and men and women had a high level of religious literacy, but Tashkent and the Prezhevalsk district of the Ettisuv oblast some of them have been converted to Islam. 
They also created marriages with the representatives of other European nationalities and were Russified, but strictly adhered to their family traditions.

The peoples of the Baltic States have been active in Turkestan in the military, medical, sanitary, public, administrative and judicial spheres, private enterprise, post, telegraph and construction, science, literature and art, clothing, forestry, animal husbandry, mining and trade.

\section{CONCLUSION}

In conclusion, it will be possible to say that the representatives of the Baltic nation initially massively came to Turkestan as military men, but later they could be seen in the fields of agriculture, medicine, education and technology. In Turkestan, they communicated in their languages only among themselves, and in other cases they spoke in Russian. They paid special attention to their national, religious traditions, and in some cases assimilated more with representatives of Russian and other European nationalities. We believe that the materials in this article will play an important role in further strengthening the economic, cultural and diplomatic ties not only between Uzbekistan, but also all the countries of Central Asia and the Baltic countries.

\section{ACKNOWLEDGMENT}

The authors wish to thank the Ministry of Education of the Republic of Uzbekistan, the National University of Uzbekistan and the State Education Development Agency Republic of Latvia. This study was supported in part by a grant from the Latvian state scholarship and supported by the National University of Uzbekistan.

\section{REFERENCES}

1. Saipova, K. (2016) Implementation of the Soviet policy of national minorities in Uzbekistan: BULLETIN OF SCIENCE AND EDUCATION № 10 (22) 2. - Pp. 39-40;

2. Matveev, A.M. (1977) Immigrants from abroad in Turkestan on their way to Great October. Tashkent; Matveev A.M. (1966). From the history of European immigrants in Turkestan after the February revolution. Scientific works of the Tashkent State University.. Issue 422; Inoyatov, Kh.Sh. (1986). Victory of the October Revolution in Uzbekistan; Zhukova, L.(1998). To the history of the Roman Catholic church in Tashkent. To the history of Christianity in Central Asia. Tashkent, Zhukova L.I (1998). To the history of the Roman Catholic church in Tashkent. To the history of Christianity in Central Asia. Tashkent,

3. Ethnic Atlas of Uzbekistan. Open Society Institute Assistance Foundation Uzbekistan, 2002). Pp. 144-150

4. Lisitskaya, O. V. (2007) History of Catholic communities in Turkestan (second half of the 19th century - 1917). Autoref. Applying for Candidate of Historical Sciences. Tashkent. 2004; Raxbarxon Murtazaeva (2007) Internet Relations And Tolerance In Uzbekistan. T, 2007; K.D.Saipova Kamola (2016) Implementation of the Council of the National Police in Uzbekistan .// Bulletin of Siense and Eduction. No. 10 (22) 2. - PP 3940

5. Khomitov, R. (2015). Relations between Uzbekistan and Latvia, Lithuania and Estonia at a new stage (1991-2014). Pp.9-10. Tashkent. Turonzamin ziyo.

6. Choriev, S. S. (2019). The history of Baltic nation diaspora in Uzbekistan. ISJ Theoretical \& Applied Science, 02 (70), 1925.

7. Nazarov A. Yo. (2020). Scientific societies in the Turkestan governorate-general as an instrument of colonial statehood (archival source study). Journal of Critical Reviews 
ISSN- 2394-5125 Vol 7, Issue 7, P. 1068-1073. http://dx.doi.org/10.31838/jcr.07.07.195

8. Rakhmankulova, Z. (2020). The National library of Uzbekistan as a digital humanities Center In Uzbekistan. The American Journal of Social Science and Education Innovations (ISSN - 2689-100x). impact factor 2020: 5 . 525. OC LC - 1121105668. October 12. Pp 2533

https://doi.org/10.37547/tajssei/Volume02ls sue10-05

9. Choriev, S.S. (2017) CLASSIFICATION OF THE TURKESTAN ASSR DOCUMENTATION IN THE CENTRAL STATE ARCHIVE OF THE REPUBLIC OF UZBEKISTAN. ISJ Theoretical \& Applied Science, 12 (56): Pp 50-54.

10. Gornukhova, A. (2004). Migracionnie processi v respublikah Pribaltiki v XX veke. diss... kand.econom. nauk. Pp.45-47. Moscow.

11. Khomitov, R. (2015). Relations between Uzbekistan and Latvia, Lithuania and Estonia at a new stage (1991-2014). Pp.9-10. Tashkent. Turonzamin ziyo.

12. Polovnikova, I. (1997). Trade Routes of Baltic amber in Central Asia (antiquity, Middle Ages). City I caravanserai on the Great Silk Road. Thesis for the UNESCO workshop. (pp. 27-28). Urgench.

13. Gornukhova, A. (2004). Migracionnie processi v respublikah Pribaltiki v XX veke. diss...kand.econom. nauk. Pp.45-47. Moscow.

14. Ethnic Atlas of Uzbekistan. (2002). Open Society Institute-Assistance Fund Uzbekistan, -Pp. 144-148, 254-255.

15. Choriev, S.S. (2019). The history of Baltic nation diaspora in Uzbekistan. ISJ Theoretical\&Applied Science, 02 (70), Pp 1925.

16. The first general census of the population of the Russian Empire, (1897). LXXXI Syr-Darya region. Publications of the Central Statistical Committee of the Ministry of Internal Affairs. Under. Edited by Troinitskago, A.N. St. Petersburg, Pp.56-57
17. The first general census of the population of the Russian Empire, (1897)., (1904). LXXXIX Fergana region. / Publications of the Central Statistical Committee of the Ministry of Internal Affairs. Under. Edited by A.N. Troinitskago. St. Petersburg, Pp.60-61

18. The first general census of the population of the Russian Empire, (1897). LXXXVI SyrDarya region. Publications of the Central Statistical Committee of the Ministry of Internal Affairs. Under. Edited by Troinitskago, A.N.(1897). St.Petersburg. Pp. 104-105; The first general census of the population of the Russian Empire, LXXXIII Samarkand region. / Publications of the Central Statistical Committee of the Ministry of Internal Affairs. Under. Edited by Troinitskago, A.N. (1897) St. Petersburg. Pp.84-85; The first general census of the population of the Russian Empire, LXXXIX Fergana region. / Publications of the Central Statistical Committee of the Ministry of Internal Affairs. Under. Edited by Troinitskago A.N.(1904).. St. Petersburg,. Pp.102-103; The first general census of the population of the Russian Empire. LXXXV Semerechinskaya oblast. / Publications of the Central Statistical Committee of the Ministry of Internal Affairs. Under. Edited by Troinitskago A.N.(1905) St. Petersburg, . Pp.80-81.

19. The first general census of the population of the Russian Empire, (1897). 1905. LXXXVI Syr-Darya region. / Publications of the Central Statistical Committee of the Ministry of Internal Affairs. Under. Edited by Troinitskago A.N. (1897). St. Petersburg, p. 132-133; The first general census of the population of the Russian Empire, LXXXIII Samarkand region / Publications of the Central Statistical Committee of the Ministry of Internal Affairs. Under. Edited by Troinitskago, A.N.(1905).. St. Petersburg, Pp.98-99; The first general census of the population of the Russian Empire, 1897. LXXXIX Fergana region. / Publications of the Central Statistical Committee of the 
Ministry of Internal Affairs. Under. Edited by Troinitskago, A.N.(1904) St. Petersburg. Pp.118-119; The first general census of the population of the Russian Empire, 1897 LXXXV Smerechinskaya oblast. Publications of the Central Statistical Committee of the Ministry of Internal Affairs. Under. Edited by. Troinitskago,A.N (1995). St. Petersburg, -Pp.96-97.

20.Abdurakhimova, N., Ergashev, F. (2002). Tsarist colonial system in Turkestan. Tashkent: Academy. -P.76

21. Rakhmankulova, Z. B., \& Rakhmankulova, $M$. B. (2019). SOME PECULIARITIES OF THE BOOKBINDING IN TEMURID'S EPOCH. Theoretical \& Applied Science, (10), 266-272.

22. Rahmankulova Z. Ottoman Empire and the political activity of England in Central Asia in the 19 th century. European Society for Central Asian Studies Tenth Conference. Central Asia Sharing Experiences and Prospects. Ankara. 2007.

23. Rahmankulova Z. Rejuvenating silkroad: past present and future of Turkey-Uzbekistan relations. 1 st edition Istanbul Sabahattin Zaim university publications. - Turkey. 2019. - pp. 185-186

24. Rahmankulova $Z$. Birinci dunya savasi ve Turkistan. Uluslararasi Asya ve Africa calismalari kongresi. 38. ICANAS (bildiri ozetleri). Ankara. 2007. p.304

25. Rakhmankulova, Z., Choriev, S., Yusupova, D., \& Muminov, O. The Historiography Of The Relations Between Central Asian Khanates And Ottoman Empire In The 19 th and At The Beginning Of The 20 th Centuries.

26.Чориев Ш., Рахмонкулова 3. (2016). Материалы личных фондоа ЦГА РУз о деятельности русских востоковедов в Туркестане. “Личность и время. Николай Остроумов: востоковед, просветитель, летописец эпохи" Матер.междунар.научн.конф. Ташкент, Pp. 67-78

27. Omonov, Q., \& Karimov, N. (2020). Importance Of Ancestoral Heritage. The
American Journal of Social Science and Education Innovations, 2(09), 196-202.

28. Rasuljanovna, I. N., \& Rakhmonqulovich, K. N. (2020). Trade Relations Between Ancient Bacteria And China On The II-I BC. The American Journal of Social Science and Education Innovations, 2(07), 47-51.

29.Rakhmankulova, Z. (2020). The National Library of Uzbekistan As A Digital Humanities Center In Uzbekistan. The American Journal of Social Science and Education Innovations, 2(10), 25-33.

30. Rakhmankulova, Z. B., \& Rakhmankulova, M. B. (2019). SOME PECULIARITIES OF THE BOOKBINDING IN TEMURID'S EPOCH. Theoretical \& Applied Science, (10), 266-272.

31. Rahmankulova Z. Ottoman Empire and the political activity of England in Central Asia in the 19 th century. European Society for Central Asian Studies Tenth Conference. Central Asia Sharing Experiences and Prospects. Ankara. 2007.

32. Rahmankulova Z. Rejuvenating silkroad: past present and future of Turkey-Uzbekistan reletions. 1 st edition Istanbul Sabahattin Zaim university publications. - Turkey. 2019. - pp. 185-186

33. Rahmankulova Z. Birinci dunya savasi ve Turkistan. Uluslararasi Asya ve Africa calismalari kongresi. 38. ICANAS (bildiri ozetleri). Ankara. 2007. p.304

34.Rakhmankulova, Z., Choriev, S., Yusupova, D., \& Muminov, O. The Historiography Of The Relations Between Central Asian Khanates And Ottoman Empire In The 19 th and At The Beginning Of The 20 th Centuries.

35. Omonov, Q., \& Karimov, N. (2020). Importance Of Ancestoral Heritage. The American Journal of Social Science and Education Innovations, 2(09), 196-202.

36. Rasuljanovna, I. N., \& Rakhmonqulovich, K. N. (2020). Trade Relations Between Ancient Bacteria And China On The II-I BC. The American Journal of Social Science and Education Innovations, 2(07), 47-51. 
37.Чориев Ш., Рахмонкулова 3. (2016). Материалы личных фондоа ЦГА РУз о деятельности русских востоковедов в Туркестане. “Личность и время. Николай Остроумов: востоковед, просветитель, летописец эпохи" Матер.междунар.научн.конф. Ташкент, Pp. 67-78

38. Boltabayevich, B. B., \& Shodievna, B. O. (2020). Individual Approach To The Formation Of Artistic And Creative Talents
Of Students In Art Schools. The American Journal of Social Science and Education Innovations, 2(08), 637-642.

39.Rakhmankulova, Z. (2020). The National Library Of Uzbekistan As A Digital Humanities Center In Uzbekistan. The American Journal of Social Science and Education Innovations, 2(10), 25-33. 